\title{
PENGARUH VARIASI FRAKSI VOLUME DAN ARAH SERAT PADA KOMPOSIT MATRIK RESIN POLYESTER BERPENGUAT SERAT PELEPAH LONTAR (BORASSUS FLABELLIFER) DENGAN PERLAKUAN NaOH 5\% TERHADAP KEKUATAN UJI TARIK
}

\author{
Fachri Husaini*, Sri Mulyo Bondan Respati dan Muhammad Dzulfikar \\ Jurusan Teknik Mesin, Fakultas Teknik, Universitas Wahid Hasyim \\ Jl. Menoreh Tengah X/22, Sampangan, Semarang 50236. \\ *Email: husaini91fachri@gmail.com
}

\begin{abstract}
Abstrak
Tanaman siwalan atau biasa disebut tanaman lontar adalah salah satu sebuah inovasi terbaru dalam pemanfaatan serat alam yang selama ini belum begitu banyak digunakan, siwalan atau lontar selama ini hanya masih dimanfaatkan pada buah dan daun lontar yang digunakan sebagai kerajinan, untuk pemanfaatan serat lontar belum begitu banyak dimanfaatkan karena belum banyak yang memahami akan kegunaan dan fungsi serat alam atau serat pada pelepah lontar. Dalam penelitian ini serat lontar adalah bahan utama dalam pembuatan komposit selain resin dan katalis, penelitian ini bertujuan untuk mengetahui kekuatan sebenarnya pada serat pelepah lontar dengan beberapa variasi dengan melakukan pengujian uji tarik pada komposit dengan bahan utama serat lontar, selain itu juga untuk mengetahui kekuatan nodulus elastisitas dan regangan pada komposit tersebut serta mengetahui sifat fisik pada spesimen tersebut dengan melakukan uji makro. Pembuatan komposit berawal dari pengambilan serat dari pelepah lontar yang sudah dipotong-potong sesuai ukuran dan sudah dikeringkan pada sinar matahari, setelah itu serat dilakukan perendaman pada larutan NaOH sebesar 5\% selama 120 menit untuk menghilangkan lapisan lignin pada serat, setelah itu melakukan pembuatan spesimen uji tarik dengan variasi fraksi volume serat yang berbeda yaitu variasi fraksi volume serat $0 \%, 5 \%, 10 \%, 15 \%$, serta menggunakan variasi arah serat yang berbeda yaitu arah serat searah dan arah serat acak. Untuk nilai kekuatan rata-rata uji tarik didapat pada variasi fraksi volume serat $15 \%$ dan arah serat searah dengan kekuatan tarik sebesar 36,35 MPa, dengan nilai regangan sebesar $6,86 \%$, sedangkan nilai kekuatan tarik terendah didapat pada fraksi volume serat $0 \%$ dengan kekuatan uji tarik sebesar 13,05MPa, dengan nilai regangan sebesar 5,32\%.
\end{abstract}

Kata kunci: komposit, polyester, serat lontar, uji tarik

\section{PENDAHULUAN}

Selain sumber daya manusia, sumber daya alam adalah salah satu anugerah terbesar yang dimiliki dan dinikmati manusia selama hidup didunia. Indonesia adalah salah satu Negara yang memiliki banyak sekali sumber daya alam yang dapat dimanfaatkan dalam kehidupan sehari hari. Salah satu sumber daya alam yang dapat dimanfaatkan manusia adalah seperti tumbuhan atau tanaman, di Indonesia memiliki banyak tumbuh-tumbuhan yang dapat dimanfaatkan dari hasil tumbuhan tersebut seperti buah, kayu, kerajinan dari daun dan lain sebagainya. Pengaruh perkembangan jaman seperti sekarang ini terutama pada perkembangan ilmu dan teknologi membuat banyak peneliti untuk melakukan penelitian-penelitian tentang inovasi terbaru dalam pembuatan komposit yang kuat, ekonomis dan ramah lingkungan. Dalam bidang ilmu teknologi inovasi dalam pembuatan komposit serat alam adalah salah satu gagasan utama yang akan dipikirkan dalam pemanfaatan sumber daya alam menjadi sebuah komposit yang memiliki sifat mekanik yang kuat, ringan, ekonomis, serta ramah lingkungan. Sumber daya alam yang dapat dimanfaatkan menjadi komposit adalah serat yang terdapat pada tumbuhan-tumbuhan yang terdapat di Indonesia seperti serat pada pelepah tumbuhan lontar.

Tumbuhan lontar (borassus flabellifer) adalah salah satu tumbuhan atau tanaman yang tumbuh di Indonesia, tumbuhan ini tersebar di banyak wilayah seperti Asia tenggara, Asia selatan, India dan salah satunya Indonesia, di Indonesia tumbuhan lontar banyak tumbuh di daerah yang kering dan memiliki suhu yang cukup panas, daerah di Indonesia yang banyak dijumpai tumbuhan lontar diantaranya adalah di Tuban Jawa timur, Nusa tenggara, Sulawesi dan Jawa tengah. Tumbuhan lontar di Indonesia dalam pemanfaatannya masih kurang maksimal, karena untuk saat ini pemanfaatan tumbuhan lontar hanya terfokus pada buah lontar, daun lontar untuk kerajinan, pohon lontar untuk bahan bangunan dan kayu bakar, untuk pelepah lontar sendiri hanya dimanfaatkan sebagai kayu bakar. 
Dilihat dari pemanfaatan tumbuhan lontar yang kurang maksimal, maka alangkah baiknya jika pelepah lontar bisa dimanfaatkan untuk diambil seratnya dan bisa digunakan sebagai bahan pembuat komposit dengan serat pelepah lontar.

Serat pelepah lontar yang akan dijadikan bahan komposit harus dilakukan perlakuan alkalisasi, yang bertujuan untuk menghilangkan lapisan-lapisan yang terdapat pada permukaan serat tersebut atau biasa disebut lignin supaya serat memiliki kekuatan yang lebih maksimal.

Serat yang mengalami perlakuan alkalisasi dengan penguat Natrium Hidroksida $(\mathrm{NaOH})$ akan memiliki kekuatan yang lebih kuat dibandingkan serat yang tidak mengalami alkalisasi, Maryanti dkk. (2011). Pada penelitian ini memiliki beberapa tujuan diantaranya mengetahui perbandingan kekuatan uji tarik dengan variasi fraksi volume yang berbeda dan arah serat yang berbeda.

\section{METODE PENELITIAN}

Bahan-bahan untuk pembuatan spesimen dengan pelepah lontar antara lain:

Bahan : resin polyester, katalis, $\mathrm{NaOH}$, kit Black, akuades, serat pelepah lontar.

Alat : cetakan kaca, suntikan $5 \mathrm{ml}$, gelas ukur $5 \mathrm{ml}, 100 \mathrm{ml}, 500 \mathrm{ml}$, timbangan digital, Aluminium foil, gunting, kuas, sikat kawat, gerinda potong, ampelas, sekrap, jangka sorong, mesin Uji Tarik.

Perbandingan fraksi volume serat dapat diihat pada Tabel 1.

Tabel. 1. Perbandingan fraksi volume serat untuk pembuatan spesimen.

\begin{tabular}{|c|c|c|c|}
\hline Resin & $\begin{array}{c}\begin{array}{c}\text { Pelepah } \\
\text { lontar }\end{array} \\
\end{array}$ & $\begin{array}{l}\text { Arah } \\
\text { serat }\end{array}$ & Katalis \\
\hline $100 \%$ (99ml) & $0 \%$ & - & $0,3 \mathrm{ml}$ \\
\hline $95 \%(94,05 \mathrm{ml})$ & $\begin{array}{l}5 \% \\
(4,95 \mathrm{ml}) \\
2,82 \mathrm{gr}\end{array}$ & $\begin{array}{l}\text { Acak \& } \\
\text { searah }\end{array}$ & $0,3 \mathrm{ml}$ \\
\hline $90 \%(89,1 \mathrm{ml})$ & $\begin{array}{l}10 \%(9,9 \mathrm{ml}) \\
5,64 \mathrm{gr}\end{array}$ & $\begin{array}{l}\text { Acak \& } \\
\text { searah }\end{array}$ & $0,3 \mathrm{ml}$ \\
\hline $85 \%(84,15 \mathrm{ml})$ & $\begin{array}{l}15 \%(14,85 \\
\mathrm{ml}) \\
8,46 \mathrm{gr}\end{array}$ & $\begin{array}{l}\text { Acak } \\
\text { \&searah }\end{array}$ & $0,3 \mathrm{ml}$ \\
\hline
\end{tabular}

Dalam pembuatan spesimen komposit untuk pengujian tarik menggunakan proses hand lay up dengan standar ukuran ASTM D 638M84. Berikut ini spesimen untuk uji tarik dengan standar ukuran ASTM D 638M-84, seperti pada Gambar 1.

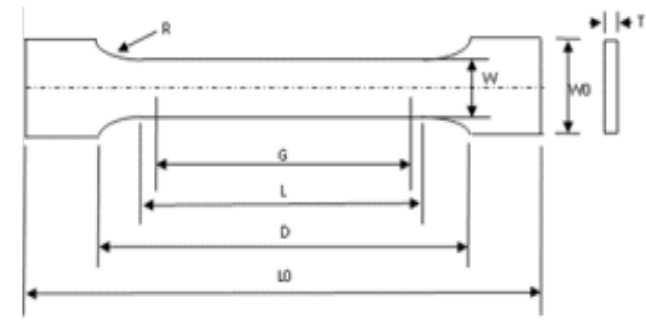

Gambar. 1. Spesifikasi cetakan ASTM D 638M-84

Ukuran cetakan ASTM D 638 M-84 M-1

$$
\begin{array}{ll}
\mathrm{T} & =4 \mathrm{~mm} \\
\mathrm{~W} & =10 \mathrm{~mm} \\
\mathrm{~L} & =60 \mathrm{~mm} \\
\mathrm{Wo} & =20 \mathrm{~mm} \\
\mathrm{Lo} & =150 \mathrm{~mm} \\
\mathrm{G} & =50 \mathrm{~mm} \\
\mathrm{D} & =115 \mathrm{~mm} \\
\mathrm{R} & =60 \mathrm{~mm}
\end{array}
$$

\section{HASIL DAN PEMBAHASAN}

Dari hasil pengujian tarik didapatkan kekuatan tarik, regangan dan modulus elastisitas. Untuk data yang diperoleh dapat dilihat pada diagram kekuatan tarik, regangan dan modulus elastisitas rata-rata. Seperti pada Gambar 2, Gambar 3, Gambar 4 dibawah ini.

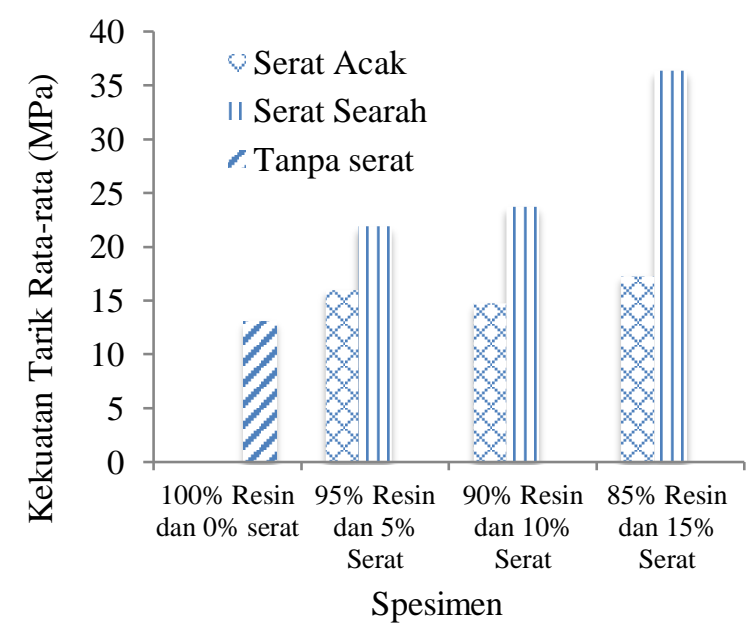

Gambar. 2. Diagram Kekuatan Tarik Rata-rata

Dari diagram kekuatan tarik rata-rata pada Gambar. 2 diperoleh hasil bahwa pada fraksi volume $85 \%$ resin dan $15 \%$ serat searah memiliki nilai kekuatan tarik tertinggi yaitu 36,35 MPa. Sedangkan kekuatan tarik komposit 
terendah terdapat pada variasi tanpa serat dengan nilai sebesar 13,05 Mpa.

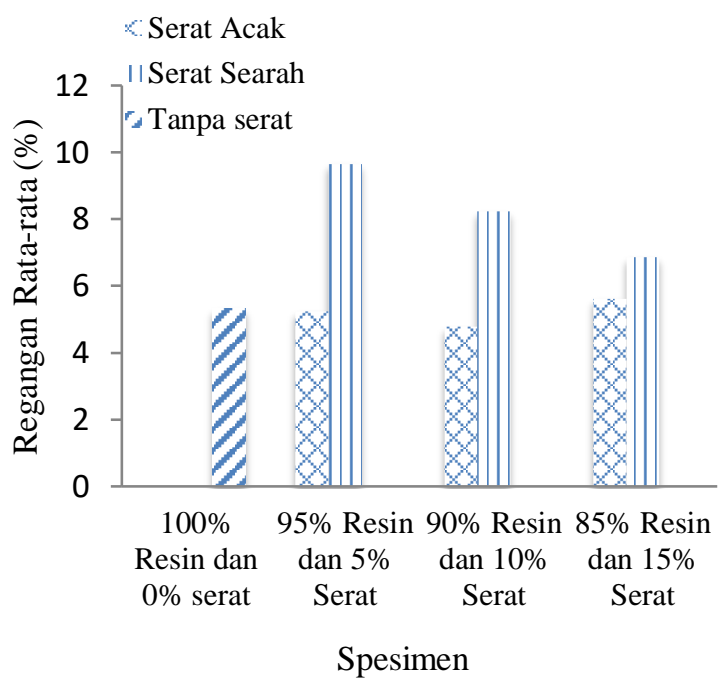

Gambar.3. Diagram Regangan Rata-rata.

Dari diagram regangan rata-rata pada Gambar.3 menunjukkan regangan tarik komposit tertinggi terdapat pada fraksi volume 95\% resin 5\% serat searah dengan nilai regangan sebesar $9,65 \%$, dan nilai regangan terendah terdapat pada fraksi volume $90 \%$ resin dan $10 \%$ serat acak dengan nilai $4,78 \%$.

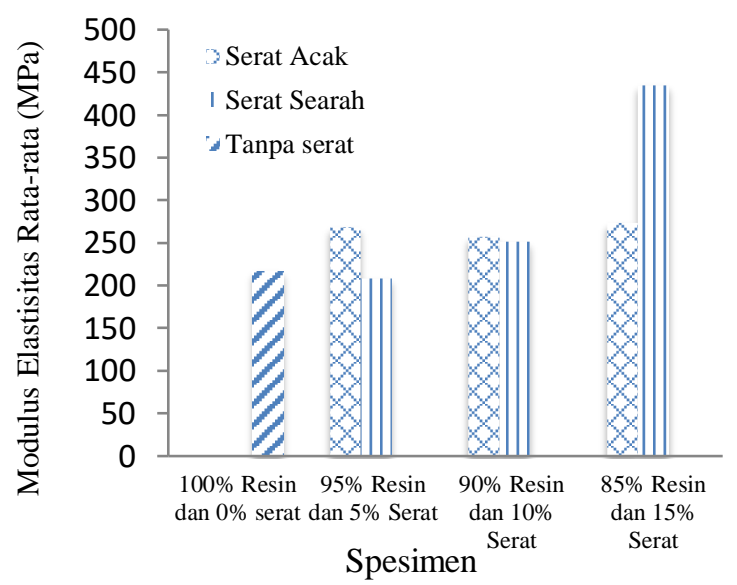

Gambar. 4 Modulus Elastisitas Rata-rata

Dari diagram modulus elastisitas rata-rata pada Gambar. 4 diperoleh hasil bahwa pada fraksi volume $85 \%$ resin dan $15 \%$ serat searah mempunyai jumlah rata-rata modulus elastisitas terbesar yaitu 434,84 MPa. Sedangkan nilai modulus elastisitas terendah terdapat pada variasi fraksi volume $95 \%$ resin dan $5 \%$ serat searah dengan nilai 208,6 Mpa.
Gambar foto makro penampang patahan spesimen setelah dilakukan uji tarik, Berikut hasil pengamatan foto makro dari penampang patahan spesimen.

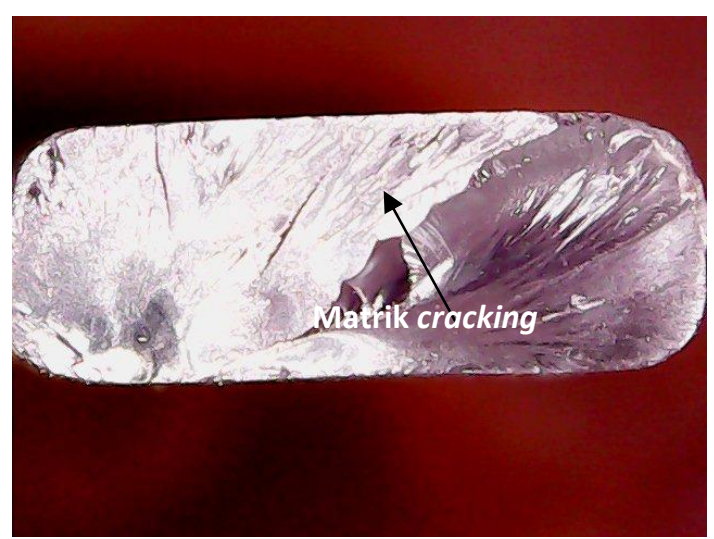

Gambar 5. Fraksi volume matriks tanpa serat

Dari Gambar.5 dapat dilihat patahan pada spesimen uji tarik matriks resin polyester mengalami patah lebih dari dua bagian dan patahan yang terjadi menunjukkan bahwa matriks resin polyester yang digunakan dalam penelitian ini memiliki sifat yang getas. Spesimen patah menjadi lebih dari dua bagian atau banyak terjadi retakan matriks (matrik cracking) yang cukup panjang di dekat daerah patahan (Taufik, 2013).

Hal ini terjadi karena tidak adanya penguat atau serat yang terdapat pada komposit sehingga kerapatan matriks sangat rendah dan matriks tidak dapat menyerap energi pada saat pembebanan. Pada saat terjadi penarikan terjadi retakan matriks yang menyebabkan terlepasnya ikatan matriks pada spesimen uji tarik. Pada fraksi volume matriks tanpa serat mempunyai nilai kekuatan tarik paling rendah dibandingkan dengan yang lainya yaitu sebesar 13,05 Mpa.

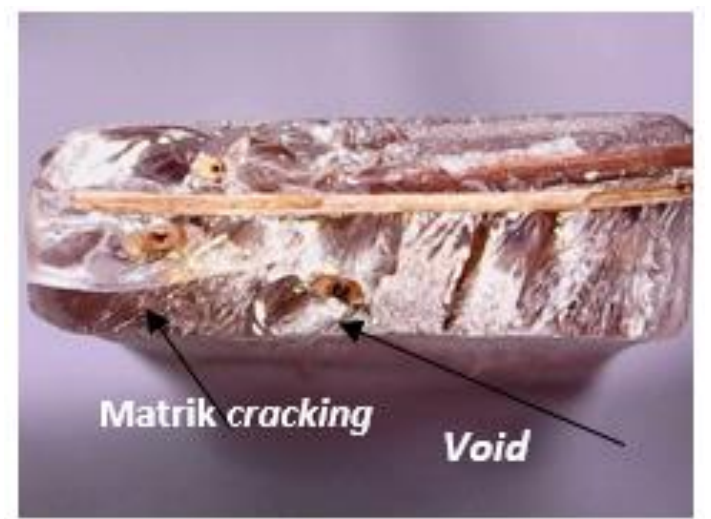

Gambar. 6. Foto makro fraksi volume $95 \%$ resin dan $5 \%$ serat acak. 


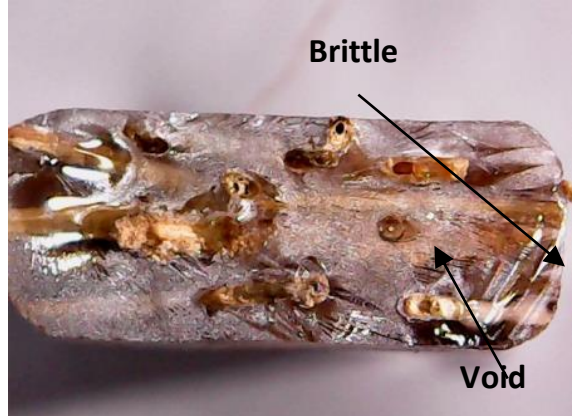

Gambar.7. Foto makro fraksi volume $90 \%$ resin dan $10 \%$ serat acak

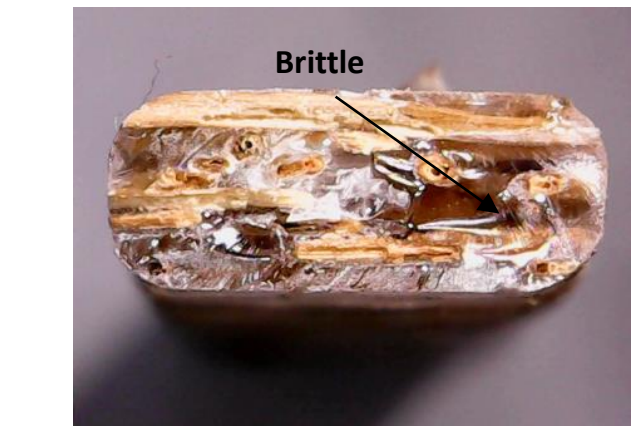

Gambar.8. Fraksi volume 85\% resin dan 15\% serat acak.

Dari Gambar.6,7,8. dapat dilihat patahan pada spesimen uji tarik fraksi volume serat acak, dapat dilihat terjadi beberapa macam sifat yang terdapat pada patahan diantaranya, matrick cracking, void, brittle. Pada patahan penampang spesimen terdapat matrik cracking hal ini membuat kekuatan tarik dari komposit ini menurun, karena matriks lebih dominan dalam menahan beban saat dilakukan penarikan (Taufik, 2013). Dari Gambar di atas juga terjadi void yang terletak di permukaan patahan, semua itu harus dihindari karena dengan adanya void pada komposit akan dapat mengurangi tingkat kekuatan. Void ini terjadi karena adanya udara yang terjebak pada saat dilakukan pencetakan (Taufik, 2013).

Selain Void dan matrick cracking dan brittle juga harus dihindari karena juga sangat mempengaruhi kekuatan uji tarik pada sebuah spesimen. Pada gambar.6,7,8, kekuatan tarik rata-rata tertinggi didapat oleh variasi volume $85 \%$ resin dan $15 \%$ serat dengan kekuatan tarik sebesar 17,27 Mpa, dan kekuatan tarik rata-rata terendah didapat oleh variasi volume $90 \%$ resin dan $10 \%$ serat dengan kekuatan tarik sebesar 14,73 Mpa.

Dari Gambar.9,10,11. dapat dilihat patahan pada spesimen uji tarik fraksi volume serat searah, dapat dilihat terjadi beberapa macam sifat yang terdapat pada patahan diantaranya, void, brittle, fiber pull out. Pada patahan penampang spesimen terdapat brittle hal ini membuat kekuatan dari komposit berkurang karena terjadi brittle atau patah getas, brittle diakibatkan karena saat pencampuran katalis dan resin kurang merata sehingga katalis tidak tercampur dengan sempurna dan mengakibatkan brittle.

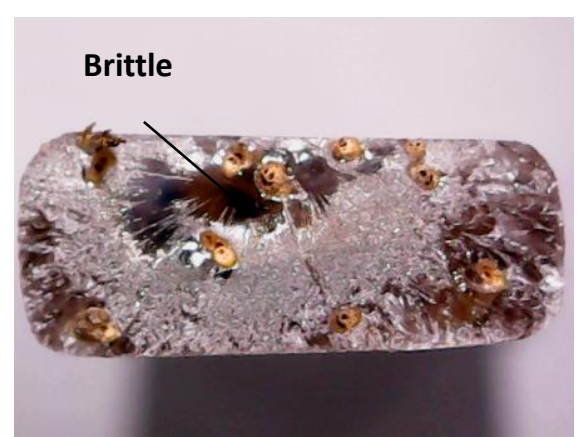

Gambar.9. Foto makro fraksi volume 95\% resin dan 5\% serat searah

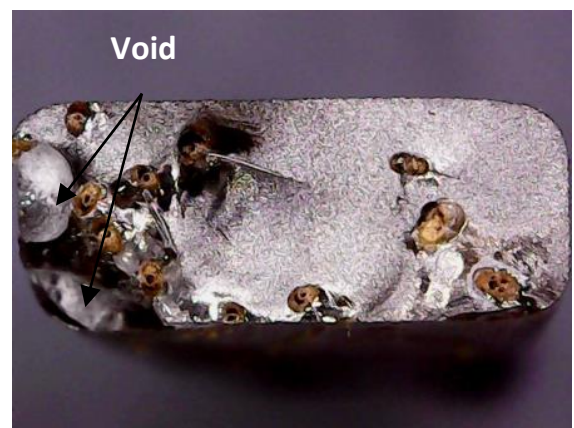

Gambar.10. Foto makro fraksi volume $90 \%$ resin dan $10 \%$ serat searah

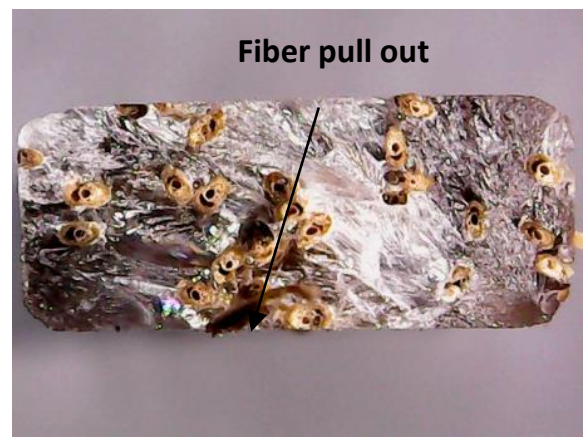

Gambar.11. Foto makro fraksi volume $85 \%$ resin dan $15 \%$ serat searah.

Selain itu ada beberapa ikatan serat yang kurang menyatu dengan matriks yang digunakan (resin polyester) sehingga serat lepas (fiber pull out). Dimana spesimen yang mengalami terjadinya fiber pull out akan mengakibatkan debonding.

Pada gambar 9,10dan 11. kekuatan tarik rata-rata tertinggi didapat oleh variasi volume $85 \%$ resin dan $15 \%$ serat dengan kekuatan tarik 
sebesar 36,35 Mpa, dan kekuatan tarik rata-rata terendah didapat oleh variasi volume $95 \%$ resin dan $5 \%$ serat dengan kekuatan tarik sebesar 21,91 Mpa.

\section{KESIMPULAN}

Berdasarkan penelitian dan uraian di atas maka didapatkan kesimpulan:

1. Nilai rata-rata kekuatan tarik variasi fraksi volume matriks dan arah serat didapat oleh komposit dengan variasi volume $85 \%$ resin dan $15 \%$ serat searah dengan kekuatan tarik 36,35 Mpa. Sedangkan rata- rata kekuatan tarik minimum rata-rata variasi volume matriks tanpa serat dengan kekuatan tarik sebesar 13,05 Mpa. Nilai regangan tertinggi terdapat pada komposit variasi volume $95 \%$ resin dan $5 \%$ serat searah dengan nilai regangan sebesar $9,65 \%$. Dan nilai regangan terendah terdapat pada fraksi volume $90 \%$ resin dan $10 \%$ serat acak dengan nilai regangan $4,78 \%$. Pada komposit variasi volume $85 \%$ resin dan $5 \%$ serat searah memiliki rata-rata modulus elastisitas tertinggi dengan nilai sebesar 434,84 Mpa. Dan nilai modulus elastisitas terendah terdapat pada fraksi volume $95 \%$ resin dan $5 \%$ serat searah dengan nilai sebesar 208,6 Mpa.

2. foto makro dalam penelitian di atas yang dapat dilihat pada penampang patahan spesimen uji adalah fiber pull out, matrik cracking, brittle, dan void.

\section{DAFTAR PUSTAKA}

ASTM D-638 dan ASTM D-695, 1990, Standard and Literature References for Composite Materials, 2nd, American Society For Testing Materials. Philiadelphia: PA.

Budha Maryanti, A. As'ad Sonief dan Slamet, W., 2011, Pengaruh Alkalisasi Komposit Serat Kelapa Poliester Terhadap Kekuatan Tarik. Teknik Mesin Universitas Brawijaya. Malang.

Nurudin, A., Sonief, A.A., Atmodjo, W.Y., 2011, "Karakterisasi Kekuatan Mekanik Komposit Berpenguat Serat Kulit Waru (Hibiscus Tiliateus) Kontinyu Laminat Dengan perlakuan Alkali Bermatrik Polyester". Jurusan Rekayasa Mesin.

Taufik, M.I., Sugiyanto dan Zulhanif, 2013, Perilaku Creep pada Komposit Polyester dengan Serat Kulit Bambu Apus. Jurnal Fema Vol. 1, No. 1. Teknik Mesin. Universitas Lampung.

Zainnuddin, 1996, "Komposit Ijuk Serat Panjang dengan Resin Polyester" Skripsi, Medan: FMIPA,USU. 